Utah State University

DigitalCommons@USU

All U.S. Government Documents (Utah Regional U.S. Government Documents (Utah Regional Depository)

Depository)

1981

\title{
Preliminary Hydrologic Evaluation of the North Horn Mountain Coal-Resource Area, Utah
}

\author{
M. J. Graham \\ John E. Tooley \\ Don Price \\ U.S. Geological Survey
}

Follow this and additional works at: https://digitalcommons.usu.edu/govdocs

Part of the Environmental Indicators and Impact Assessment Commons

\section{Recommended Citation \\ Graham, M. J.; Tooley, John E.; Price, Don; and U.S. Geological Survey, "Preliminary Hydrologic Evaluation of the North Horn Mountain Coal-Resource Area, Utah" (1981). All U.S. Government Documents (Utah Regional Depository). Paper 572. \\ https://digitalcommons.usu.edu/govdocs/572}

This Report is brought to you for free and open access by the U.S. Government Documents (Utah Regional Depository) at DigitalCommons@USU. It has been accepted for inclusion in All U.S. Government Documents (Utah Regional Depository) by an authorized administrator of DigitalCommons@USU. For more information, please contact digitalcommons@usu.edu.

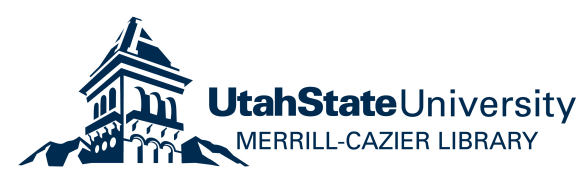


UNITED STATES

DEPARTMENT OF TAE II. ERIOR

GEOLOGICAL SURVEY

PRELIMINARY HYDROLOGIC EVALUATION OF THE NORTH

HORN MOUNTAIN COAL-RESOURCE AREA, UTAH

By M. J. Graham, John E. Tooley, and Don Price

U.S. GEOLOGICAL SURVEY

OPEN-FILE REPORT 81-141

PREPARED IM COOPERATION WITH THE

U.S. BUREAU OF LAND MANAGEMENT
ONITED STATES DEPARTMENT OF THE INTERIOR JAMES G. WATT, Secretary

GEOLOCICAL SURVEY

Doyle G. Frederick, Acting Director

District Chief

D.s. Geological Survey

Room 1016 Administration Building

1745 West 1700 South
Salt Lake City, Utah 84104 
Location and physiographic setting

Geologic setting

Water resources

Surface water

Runofr
Quality

Use .........

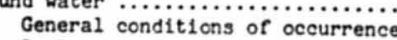

Recharge and movement

Quallty ......

Some potential 1

fects of ccil mining on the water resources

Ground water

Conclusions

References oited

\section{ILLUSTRATIONS}

Figure 1. Map showing location of the North Horn Mountain area.
2. Map showing geokraphic features, hydrologic-data sites, and theoretical mean annual runoff in Mountain area.

3. Diagramatic geologic section of the North Horn Mountain are

4. Graphs showing maximum, median, and minimum monthly runoff, average annual runoff, and recorded runoff
extremes in Cottonwood extremes in Cottonwood Creek at gaging station 09324500
and Ferron Creek at gaging station $09326500 \ldots \ldots \ldots \ldots \ldots . .$.

5. Flow-duration graphs for Cottonwood Creek at gaging station 09324500 for the periods before and after olosure of Joes Valley Reservoir early in water

6. Flow-duration graph for the period $1971-23$ and $1947-78$ for

7. Graph of Creek at gaging station $09326500 \ldots \ldots \ldots \ldots \ldots$. Graph of log-Pearson Type III analysis of annual peak
discharges recorded in Cottonwood Creek at gaging

6. Gation 09 . d1scharges recorded in Ferron Creek at gaging station

Diagrammat1c section through North Horn Mountain showing

10. Map showing location of observation wells and springs 1nvestigated on North iorn Mountain

Table 1. Selected data for stread-gaging stations in the North Horn

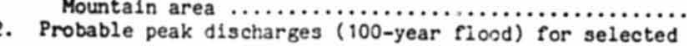
Probable peak discharges

Selected water-quality data for Cottonwood and Ferron

3. Selected

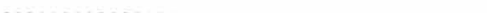
Measured suspenced sediment in Cottonwood Creek at gaging

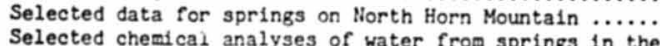
6. Selected chemicai analyses of water from springs in the
North Horn Mountain area $\ldots \ldots \ldots \ldots \ldots \ldots \ldots \ldots \ldots \ldots \ldots \ldots \ldots \ldots \ldots \ldots$
Page

11 


\section{COEVERSION FACTORS}

Numbers in this report are given in insh-pound units. For those readers who may prefer to use metric units rather than inch-pound units, the

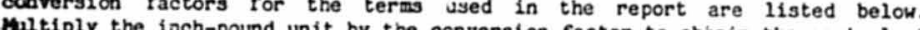
metric unit.

\begin{tabular}{|c|c|c|c|}
\hline Inch-pou & $\begin{array}{l}\text { ad } \\
\text { Abbreviation }\end{array}$ & $\begin{array}{l}\text { Conversion } \\
\text { factor }\end{array}$ & Metric unit \\
\hline Acre-foot & acre-ft & $1233^{0.001233}$ & $\begin{array}{l}\text { Cub1c hectometer } \\
\text { Cub1c meter }\end{array}$ \\
\hline $\begin{array}{l}\text { Acre-foot } \\
\text { per square mile }\end{array}$ & acre-ft/mi ${ }^{2}$ & 0.000476 & $\begin{array}{l}\text { Cubic hectometers } \\
\text { per square k1lometer }\end{array}$ \\
\hline $\begin{array}{l}\text { Cuble root } \\
\text { per second }\end{array}$ & $\mathrm{ft}^{3} / \mathrm{s}$ & 0.02832 & $\begin{array}{l}\text { Cub1c meter per } \\
\text { second }\end{array}$ \\
\hline Foot & ft & 0.3048 & Meter \\
\hline $\begin{array}{l}\text { Gallon per } \\
\text { minute }\end{array}$ & gal/min & 0.06309 & Liter per second \\
\hline Inch & 1n. & $\begin{array}{l}25.40 \\
2.540\end{array}$ & $\begin{array}{l}\text { Millimeter } \\
\text { Cent1meter }\end{array}$ \\
\hline nille & $\mathbf{m}$ & 1.609 & R1lometer \\
\hline
\end{tabular}

PRELIMINARY HYDROLOGIC EVALUATION OF THE MORTH HORN NOUSTAIN COAL-RESOURCES AREA, UTAH (with a section on some potential 1mpacts of atevert on the water mources)

By M. J. Graham, J. E. Tooley, and Don Price ABSTRACT

North Horn Mcuntain is part of a deeply dissected plateau in central Utah which is characterized by deep, narrow, steep-walled canyons with loca Mountain area range in age from Late Cretaceous to Holocene and contain two mineable seams of Cretaceous coal. The area is in the drainage basin of the San Rafael River, in the Colorado River Basin. Runoff from the mountain is ephemeral. This runoff to the San Rafael River is by way of Cottonwood and Ferron Creeks and represents less than 10 percent of their average annual draining North Horn Mountain are estifated to range from the ephemeral streams second.

The chemical quality of surface water in the area is good. The water is generally of a calcium magnesiun bicarbonate type with average dissolved solids less than 500 milligraes per 1iter. Annual sedicent yield in most of the area ranges from 0.1 to 0.2 acre-foot per square mile but locally is as high as 1.0 acre-foot per square mile. Most of the sediment is eroded during

Most of the ground water above the coal on North Horn Mountain probably is in perched aquifers. These aquifers support the flow of snall seeps an into the coal. The principal source of recharge is precipitation that probably moves to aquifers along faults, joints, or fractures. This movement is apparently quite rapid. The dissolved-3olids concentrations of ground water in the North Horn Mountain area range from less than 500 to about 1,000
milligrams per 11ter.

Coal mining on North Horn Mountain should have minor effects on the quantity and quality of surface water. The maximum predicted decrease in the annual flow of Ferron and Cottonwood Creeks is less than 4 percent. The construction were to take place during the summer cloudburst season. Subsidence, which usually follows underground coal mining, could create rock rractures through which a perched aquifer might be crained, thus depleting the flow of seeps or 3 pr: $:-5^{3}$ fed by that aquifer. It is considered unlikely that the mining will adyrr $-y$ affect the chemical quality of the ground water.

\section{INTRODUCTION}

Purpose and scope

In June 1978, the U.S. Geological Survey, in cooperation with the U.S. Bureau of Land Management began a 3-year study of the water resources of the 
central Wasatch Plateau, Utah. The study was undertaken to obtain hydrologic Information needed by the Bureau of Land Management to make reasonable system and (2) avoid or reduce adverse impacts on water sources. Under cocperative ag eement, the (eological Survey was to submit a preliminary report of hydrologic conditions ln the North Horn Mountain area of the central Wasatch Plateau. This report fulfills that committment.

Evaluations given in this report are based largely on hydrologic data collected prior to June generalized, and doubtless they will be refined as mor water, are highly from future drilling programs and aquifer test3. Location and physiographic setting

The North Horn Mountain area is in central Utah about 110 air miles south-sotheast of Salt Lake City (rig. 1). The principal communities in the area the economy is based chiefly on agriculture, uil in inereasing exphasis on local exphasis on energy-

North Horn Mountain is part of a deeply dissected plateau in the High Plateaus of the Utah section of the Colorado Plateaus physiographic province (Fenneman, 1931, p. 294-299). The area is characterized by deep, narrow, steep-walled canyons with local relief of Eore than 1,000 $\mathrm{ft}$. The total 6,000 ft the area 13 wore than 5,000 rt, with altitudes ranging from about Piateau west of North Horn Mountain Mountain, The Cap, has an altitude of $9,615 \mathrm{ft}(\mathrm{ft}, \mathrm{B} \cdot 2)$.

\section{Geologic setting}

Geologic units exposed in the North Horn Mountain area range in age from late Cretaceous to Holocene. They include sedidentary strata consistin chiefly of shale, mudstnee, siltstone, lenticular and Eassive sandstone, and stream-ralley alluimese strata, which are blanketed locally by talus and structural deformation. They ip northwest, and those that underlle North Horn Mountain are apparently unctby major faults. There appear to be two mineable coal seams, both in the lower part of the Blackhawk Formation. These coal seams can be seen croppin out on canyon walls above the massive Star Point Sandstone, a prominent marker bed in the region.

A1 though the rocks that underlie most of North Horn Mountain appear not to have been cut by major faults, they have been fractured and jointed. It 1 s the occurrence and movement of ground water in the areat wore, influence on dip of the strata. The geology of the North Horn Mountain area regal mapped or described in several reports and maps including those of Spleker (1931), Stokes (1964), Doelling (1972), and Johnson (1978). The reader 1s referred to those reports for more detalled information about the geology.

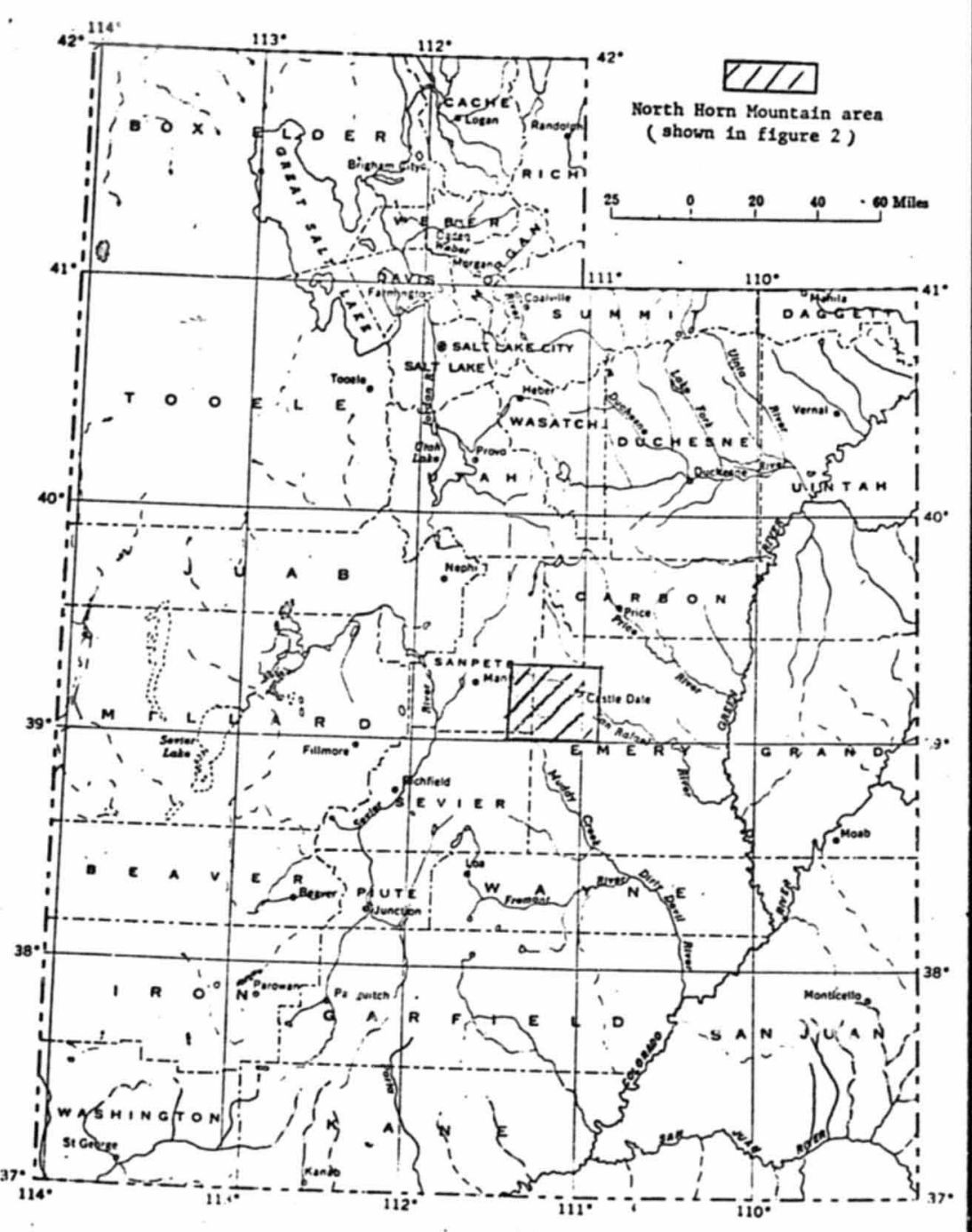

Figure 1.--Location of the North Horn Mountein area. 


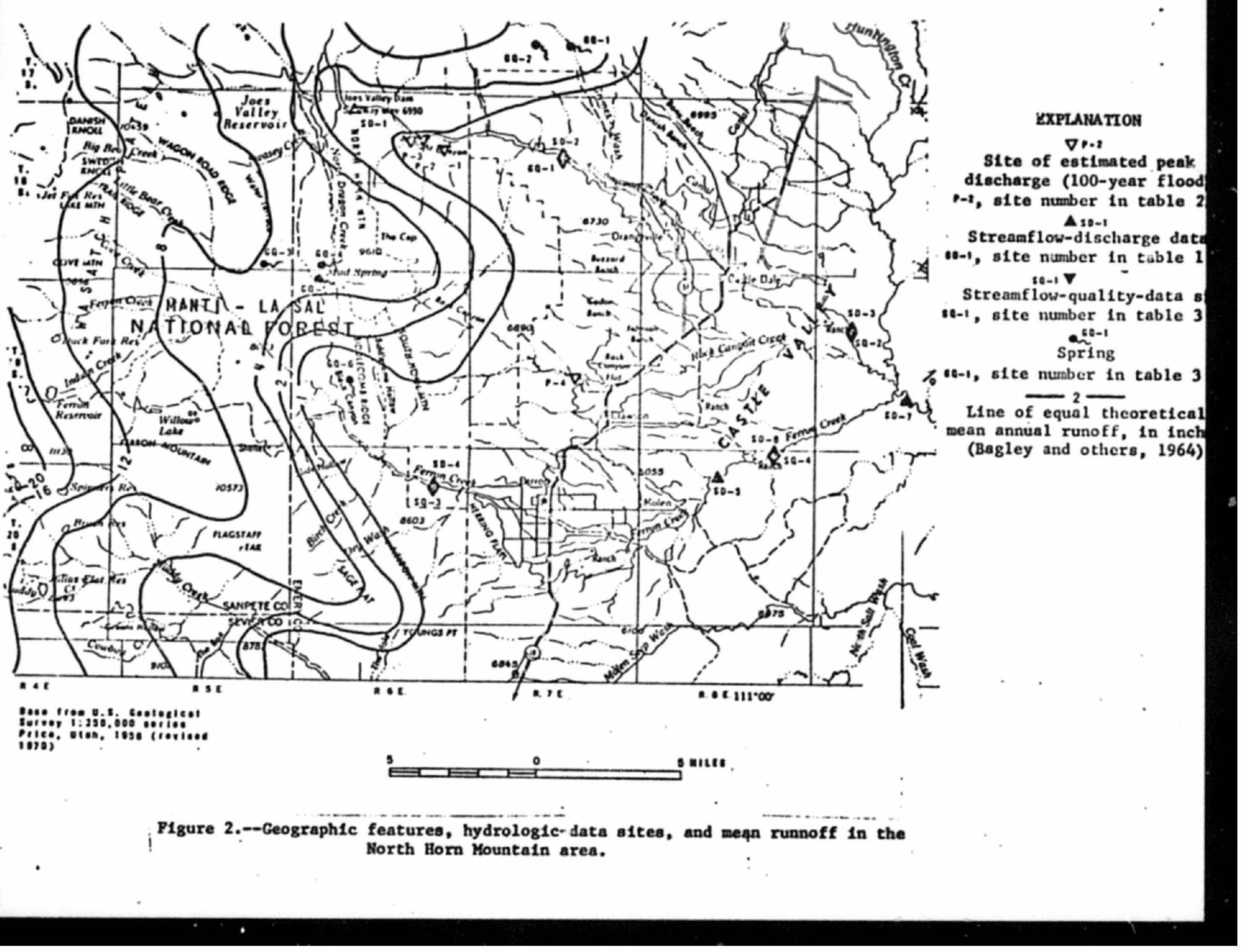




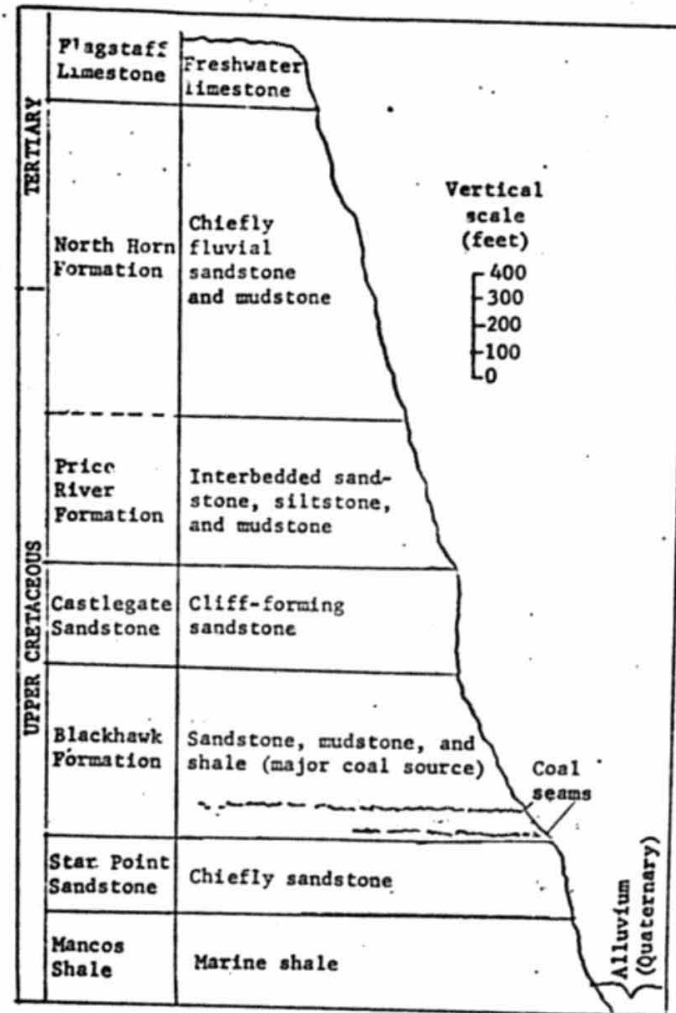

Figure 3.--Diagrarmatic geologic section of the North Horn Mountaln area (modifiea fron Utah Power of Light Co: written comeun., .1979).
Clinate

The clieate of the North Horn Mountain area is semiarld to subhumid. suring the per1od 1931-60, normal annual precip!tat: : ranged from about $81 \mathrm{in}$. In Castle Valiey to about $40 \mathrm{in}$. along the crest of the dasatch Plateau. For the same period ane localities, norzal May-Septecber precipitation ranged from about 4 to $10 \mathrm{nn}$. and norzal october-spril precipitation ranged from about to 30 n. reopection about 16,8 , and 8 in. Bureau, no date, a and b). Weather

The October-April precipitation generally comes fron frontal-type storms that affect large areas and are usually of several hours duration. The precipitation usually occurs as snow, which accurulates until it melts and runs off during the late spring or early summer. By late spring, sncy depths of several feet are comon on the north-facing slopes of North Horn Mour tain.

The May-September precipitation usually comes from localized convectiontype storms which are of short duration. The precipitation usually occurs as destruction

Mir teaperature ranges widely in the area. Midwinter temperatures often fall below freezing in Castle Valley and below $0^{\circ} \mathrm{F}$ at the higher altitudes. Midsummer temperatures often exceed $90^{\circ} \mathrm{F}$ and occasionaliy exceed $100^{\circ} \mathrm{F}$, except In the higher plateau areas. Evaporation rates are high throughout the area, averag1ng gore than 42 in. per year, even in the higher altitudes (Iorns and others, 1965, pl. 6). The high annual evaporation rates, coupled with low here preclpitation, llifts perennlal runorf to only a few streams that head areas of ground-uater resticts the principal

\section{WATER RESOURCES}

Surface water

Runor

The North Horn Mountain area is in the drainage basin of the San Rafael River, a tributary of the Green River that joins the Colorado River about 95 air malles southeast of Castle Dale. Runoff rt. North Horn Mountain to the perennial streams receive most of thetr flos fros the Wasatch Plateau west of Morth Horn Mountain-the flgher, wetter areas of comes mostly from Joes Valley Reservoir by way ol Straight Canyon "lod Coek Mountaln contributes only a small amount of the average annual flovg of those streams.

The Geological Survey has operated streamflow-gaging stations on Cottonwood Creek near Orangeville (station 09324500) since 1909 and on Ferron of cottoar Permon (station of Cottonwood Creek, as recorded at station 09324500, is regulated at Joes 


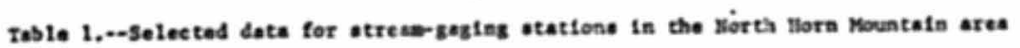

\begin{tabular}{|c|c|c|c|c|c|c|c|c|c|c|c|}
\hline \multirow[b]{2}{*}{$\begin{array}{l}\text { stce } \\
\text { No. } \\
\left.\text { (ote } \mathrm{tis}_{\mathrm{s}} .2\right)\end{array}$} & \multirow[b]{2}{*}{$\begin{array}{l}\text { v.s. Ceolos:- } \\
\text { ieal Survey } \\
\text { otation So. }\end{array}$} & \multirow[b]{2}{*}{ station } & \multirow[b]{2}{*}{$\begin{array}{l}\text { Approxiseate } \\
\text { Arafnage area } \\
\text { (oquere wileo) }\end{array}$} & \multirow[b]{2}{*}{$\begin{array}{l}\text { Pertod of } \\
\text { record }\end{array}$} & & \\
\hline & & & & & $\begin{array}{c}\text { Cuble feet } \\
\text { per } \\
\text { secoed }\end{array}$ & $\begin{array}{l}\text { Acre-feet } \\
\text { per year }\end{array}$ & Yeert & Maxion & Dote & Minta & Date \\
\hline so-1 & 09324000 & $\begin{array}{l}\text { Sealy Creek (Stratght } \\
\text { canyon) near Orante- } \\
\text { vilie. }\end{array}$ & 150 & $1953-57$ & 103 & $\cdot$ & 4 & 2,110 & $8-26-37$ & 11 & $3-16-57$ \\
\hline $50-2$ & 09324500 & $\begin{array}{l}\text { Cottonwood Creek near } \\
\text { Orangeville }\end{array}$ & 205 & $\begin{array}{l}\text { 1909-27: } \\
1932-70 ; \\
1973-78\end{array}$ & 95.1 & 68.900 & 58 & 7,220 & $8-1-64$ & 1.2 & 4- $8-66$ \\
\hline $50-3$ & 23325000 & $\begin{array}{l}\text { Cottonwood Creek nesr } \\
\text { Castle Date }\end{array}$ & $2 s 1$ & $1947-58$ & 54.8 & 39,670 & $\mathbf{n}$ & 1,660 & About & 0 & (1) $h$ \\
\hline $50-4$ & 09326500 & $\begin{array}{l}\text { Terron Creek (upper } \\
\text { station) near Verron }\end{array}$ & 140 & $\begin{array}{l}1911-23: \\
1947-78\end{array}$ & 65.6 & 47,530 & 42 & 4,180 & $3-27-52$ & 0 & (a) \\
\hline sD-5 & 09327500 & $\begin{array}{l}\text { Terron Creek near } \\
\text { Castle Dale }\end{array}$ & 210 & $\begin{array}{l}\text { 1911-14: } \\
1947-58\end{array}$ & 35.6 & 28.770 & 13. & 1,630 & 8- 3-61 & 0 & $(4 /)$ \\
\hline $50-6$ & 09327550 & $\begin{array}{l}\text { Terron Creek below } \\
\text { Faradise Ronch, nesr } \\
\text { Clowson }\end{array}$ & 221 & $1975-70$ & $*$ & $\cdot$ & $-3^{*}$ & 1,840 & $7-24-77$ & 0 & $(1 /)$ \\
\hline $50-7$ & 09320000 & 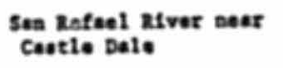 & 930 & $\begin{array}{l}1947-64 ; \\
1972-78\end{array}$ & 103 & $74,620^{\circ}$ & 22 & 4,510 & $6-3-52$ & 0 & $(1 /)$ \\
\hline
\end{tabular}

1 tho now on severel depe. 
Valley Reservolr which was closed early in water year 1966. There 1s only a minor regulation of Ferron Creek above station 09326500; this being Ferron and Duck Creek Reservoirs, which store runoff from only about 5 percent of the drainsge area upstrean frod the gaging station. Average annual gaged runof? In Cotonwood Creek at station 09324500 was about 68,900 a.tre-ft for 58 years oi record through mater year 1978 and 39,630 acre-ft since the closure of Joes Valley Reservoir. Average annual runoff in Ferron Creek at station 09326500 was 47,530 acre-ft for 42 years of record through water year 1978. As shown in figure 4, the months of highest runoff at both stations for the respective perlods of record were May and June. This runoff is chiefly in response to melting of the winter snowpacks. Iowever, regulation of the flow of Cottonwood Creek in Joes Valley Reservoir (chiefly to meet irrigation requirements) has reduced the peak discharges as measured at gaging station 09324500.

Figure 5 shows flow-duration graphs for Cottonwood Creek at station 09324500 before and after closure of Joes Valley Reservoir. Figure 6 shows the flow-duration graph for Ferron Creek at station 09326500 for the entire period of record.

As shown in figure 5, a flow of $10 \mathrm{ft}^{3} / \mathrm{s}$ in Cottonwood Creek at station 09324500 was exceeded more than 99 percent of the tine prior to closure of Joes Valley reservoir and only about 66 percent of the time since closure of the reservoir. A flcw of $10 \mathrm{ft}^{3} / \mathrm{s}$ in Ferron Creek at station 09326500 was exceeded about 80 percent of the time during the period of record for that station (fig. 6).

Although most of the runoff in Cottonwood and Ferron Creeks comes from snowmelt, the highest instantaneous discharges result from thunderstorms. For example, the highest ręcorded discharge in Cottonwood Creek at gaging station 09324500 was $7,220 \mathrm{ft}^{3} / \mathrm{s}$, August 1, 1964 (prior to closure of Joes Valley Reservolr), and that in Ferron Creek at gaging station 09326,00 was 4,180 $\mathrm{ft}^{3 / \mathrm{s}}$, August 27,1952 , both resulting from cloudbursts.

F1gures 7 and 8 are log-Pearson Type III analyses (U.S. Water Resources Counc1l, 1977) of annual peak discharges recorded in Cottonwood and Ferron Creeks at stations 09324500 and 09326500 . These graphs indicate likelihood of experiencing flood discharges exceeding specified magnitudes in any future year. For example, figure 7 indicates that there is a 5 -percent chance of a discharge of $3,200 \mathrm{ft}^{3} / \mathrm{s}$ being equalled or exceeded. The reciprocal of the exceedence probability is the average period of time between exceedences or "recurrence 1nterval" of the flood. A flood with a 5-percent exceedence probability, therefore, will be exceeded at time intervals averaging 20 years in length; but indicates no regularity of occurrence. Figure 7 is based on annual peak discharges recorded before and after closure of Joes Valley Reservolr, consequently, 1ts applicability for estimating future floods at station 09324500 (which now are influenced by regulation at Joes Valley Reservoir) is uncertain. Because of reservolr effects, a peak flow of about $1,200 \mathrm{ft}^{3} / \mathrm{s}$ may have a less than 50 percent chance of being exceeded in any 1 year. The 50-percent probability of a peak discharge of $1,000 \mathrm{ft}^{3} / \mathrm{s}$ or greater occurring in any 1 year in Ferron Creek at station 09326500 ( $\mathrm{fig} .8$ ) is wore realist1c. 

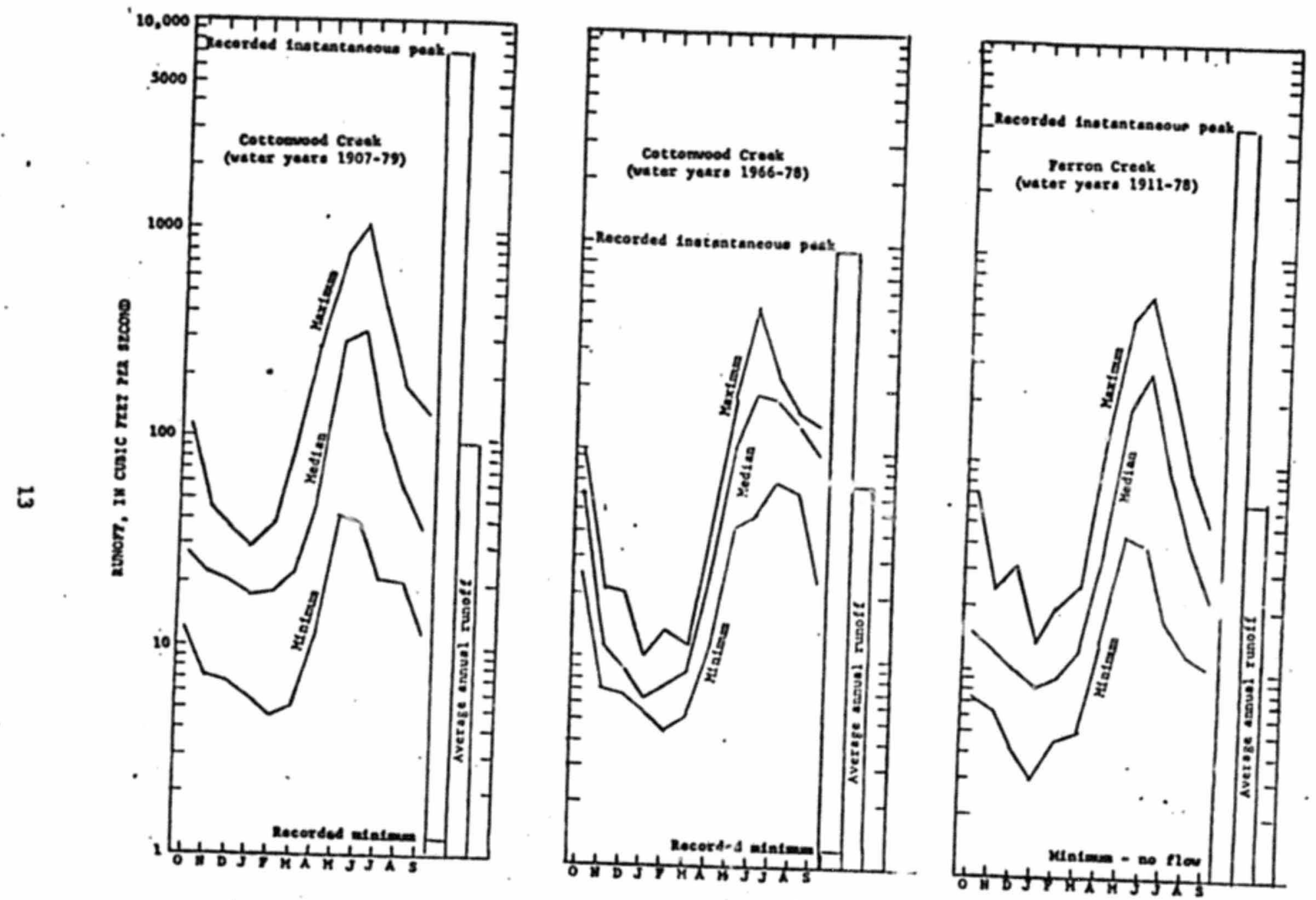

Figure 4.- Maximum, median, and ninlmum monthly runoff, average annual runoff, and recorded extremea in Cottonwood Crtek at gaging station 09324500 and Ferron Creek at gaging station 


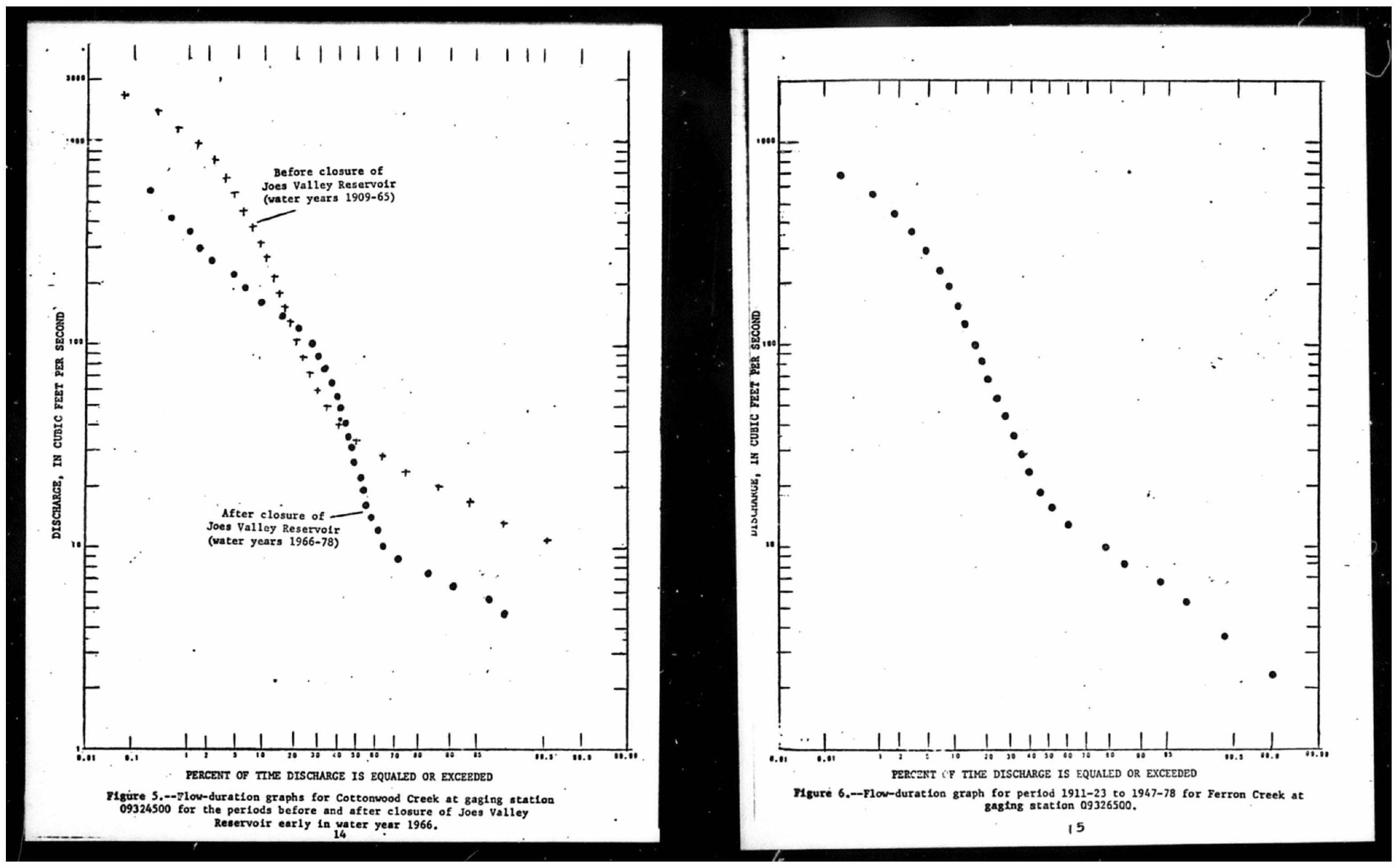




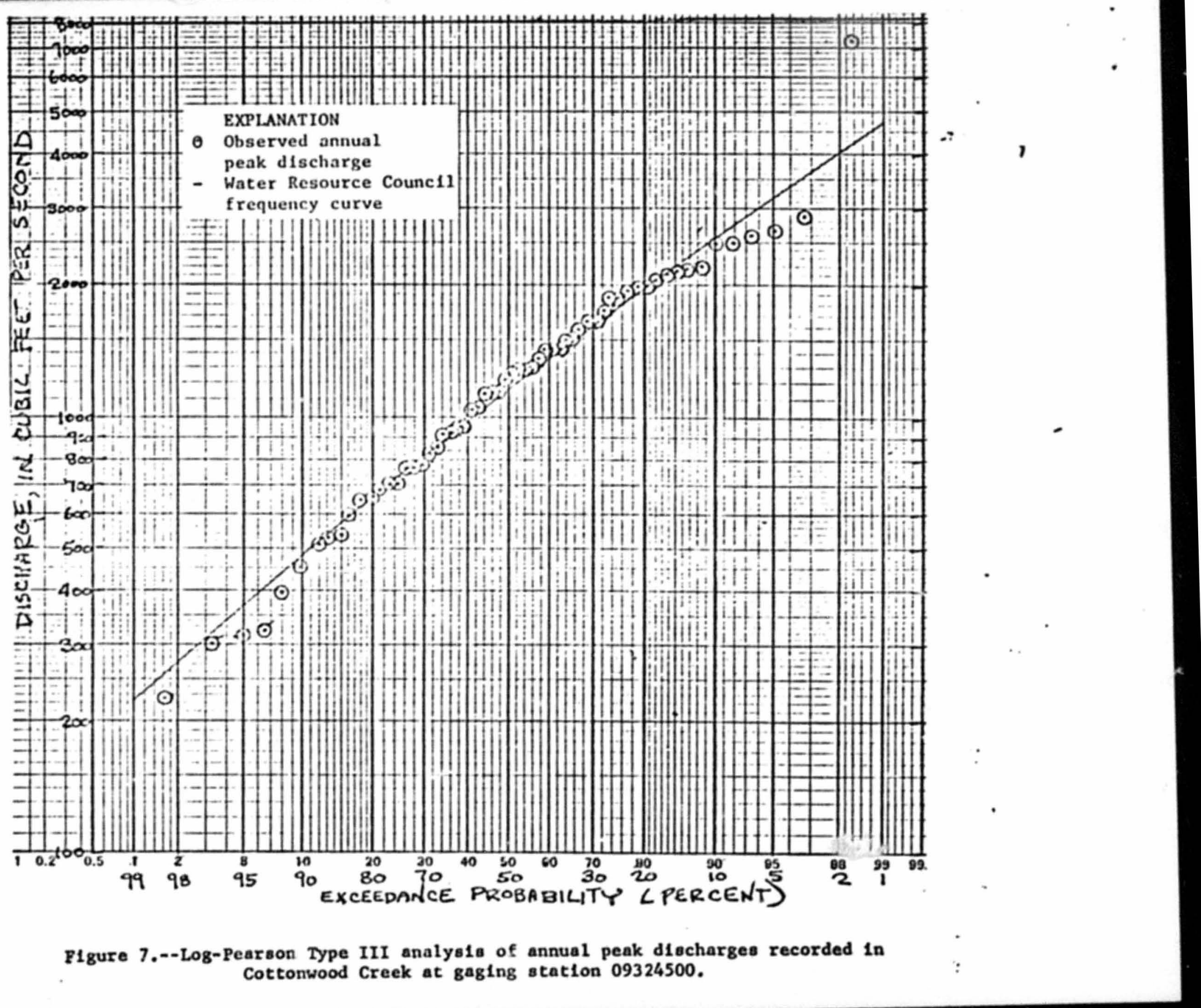




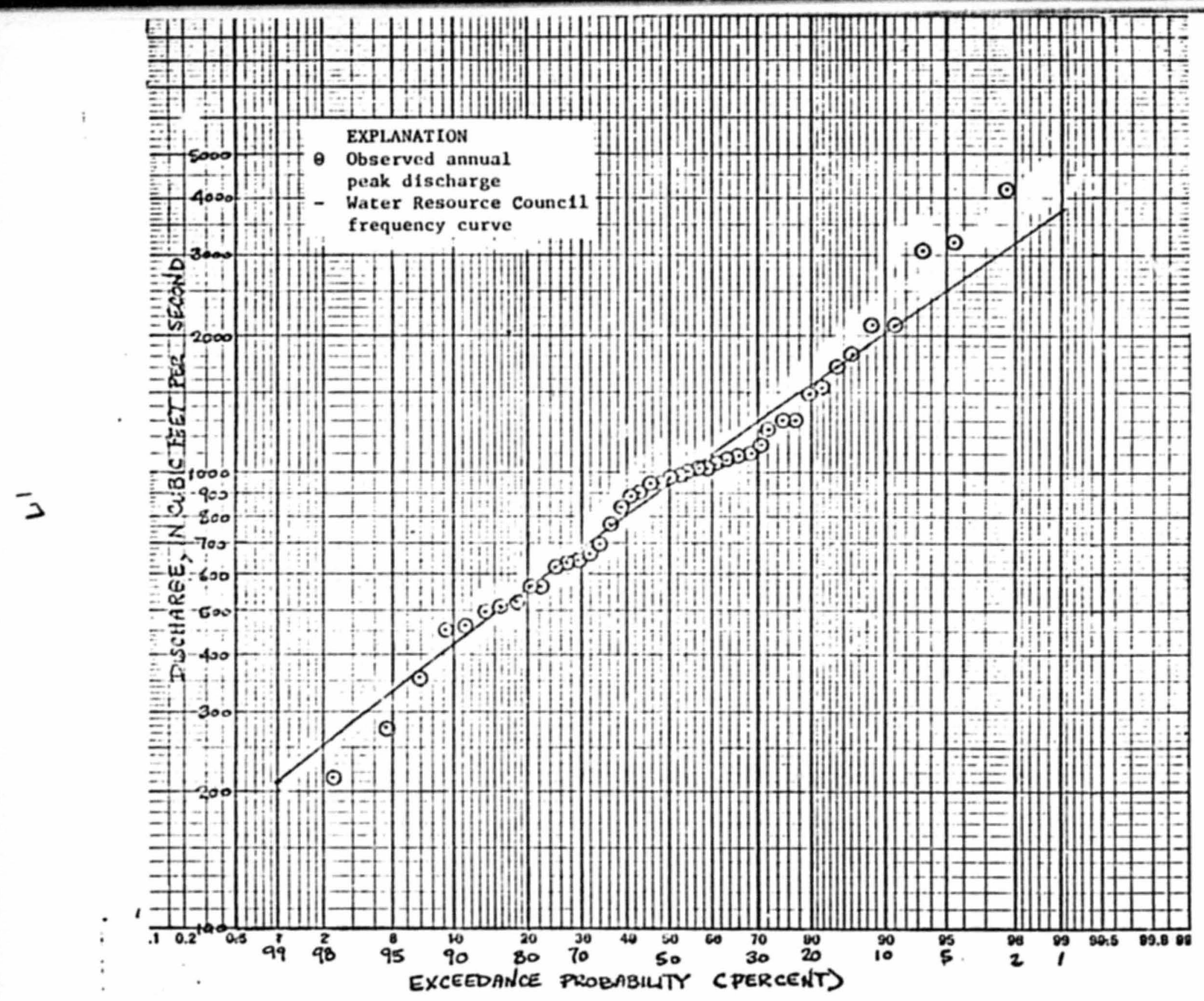

p. 133

Figure 8.--Log-Pearson Type III analysis of annual peak discharges recorded in Ferron Creek at paging station 09326500. 
Streams on North Horn Mountain are epheseral and are not gaged. Discharge from springs in the area is lost to evapotranspiration and seepage a and others, 1964, fig. 16), theoretical mean annual ruspers of Utah (Bagley Mountaln alone is estimated to be on the order of 8,000 acre- from North Horn scale map used be Bagley and others was used to make the estimate. Indicates an estimated 5,000 acre-ft (62 percent of the runoff) in cottonwood Creek, and an estimated 3,000 acre-ft (38 percent) in Ferron Creek. These amounts are only about 7 and percent, respectively, of the average annual
runoff recorded at gaging stations 09324500 and 09326500 .

Probable peak discharges (100-year flood) have been estimated for several of the epheseral streams that drain North Horn Mountain (table 2). discharges against basin characteristics for 29 long-term stations peak hydrologic characteristics similar to the North Horn Mountain drainage area. The probable peak discharges, given in table 2, are based on drainge areas and wean annual precipitation on the drainage area. They are subject to rerinement on the acquisition and analysis of stream-channel geometry data in

Table 2.--Probable peak discharges (100-year flood) for selected ephemeral streams on North Hear Mountain
(See $\mathrm{Fig}_{\mathrm{g}}$. 2)
Name
Discharge Standard erro
P-1 Clay Banks Swale
Peld and Mielson Swale
P-4 Boxk Canyon

\begin{tabular}{|c|c|}
\hline \multirow{2}{*}{\multicolumn{2}{|c|}{+231 to -148}} \\
\hline \multirow{3}{*}{$\begin{array}{l}380 \\
240 \\
240 \\
200\end{array}$} & \\
\hline & +158 to -94 \\
\hline & \\
\hline
\end{tabular}

The area Inundated by a 100-year flood would be small because lower reaches of the stream channels on North Horn Mountain are steep and narrow. The velocities and erosiveness of such a flood doubtless would be destructive to roads, buildings, and other structures in the stream bottoms.

Quallty

Avallable data indicate that the chemical quality of surface water in the North Horn Mountaln area is good. Minimum concentrations of dissolved soximum concentrations range (rom 250 to 150 ger 11ter), an f1g. 13). Numerous chemical analyses have beer, made of and others, 1979, Creek near gaging station 09324500 and in Ferron Creek near gaging station 09326500 (Waddell and others, 1978, p. 24 and 30). According to analyses, the discharge-weighted average concentration of dissolved solids at both stations is less than $500 \mathrm{mg} / \mathrm{h}$. However, the and Ferron. (See Price and Hore than 1,000 $\mathrm{mg} / \mathrm{L}$ dounstream from Cast1e Dale chlefly to the return fun solls developed on the Mano
Water upstream from stations 09324500 and 09326500 is generally of a there disolved bicar conteen $1,000 \mathrm{~g} / \mathrm{L}$, sodium and sulfate become the dominant ions.

Selected water-quality data for Cottonwood and Ferron Creeks art given In table 3. According to those data, water in the two streams upstream from stations 09324500 and 09326500 was, at the time of sampling, of good blological quallity (tupolluted) as well of as good chemical quality. There though concentrations of Strontium concentraticns of Wasatch Plateau coal-flelds area, but in such concentrations strontiun is not harmful to human healtb.

Little informaticn is avallable for fluvial sediment in the North Forn Mounta1n area. A map complied by the U.S. Soll Conservation Service (see most of the others, yly. 1.0 acre- $f t / \mathrm{mi}^{2}$.

According to J. C. Mundorff and K. R. Thompson (U.S. Geological Survey uritten comun., 1979), 90 percent or more of the suspended-sediment discharge In the San Rafael River occurs in 10 percent or less of the tige. This is attributed to the relatively large voluzes of suspended sedizent discharged during cloudbursts. In the Eore arid parts of the study area, suspendedsediment concentrations can exceed $10,000 \mathrm{mg} / \mathrm{L}$ for up to several hours during cloudburst hoods, depending on the zagnituce of those hoods. However, lar recorced was $452 \mathrm{mg} / \mathrm{L}$ on March 31

Use

The principal use of surface water--chiefly from Cottonwood and Ferron Creeks-1s for 1rrigation of several thousand acres of cropland in the Castie Dale-Ferron area. Some streamflow is also diverted for domestic supply in indugtrile, Castle Dale, Ferron, and Clawson; and soze water is diverted for 1ndustrial use. A minor amount of the area's surface-water supply is also use

The following estimates for the use of water from Cottonwood and Ferron Creek are taken from the Final Environmental Statement, Emery Power Plant (U.S. Department of the Inter1or, 1979, p. 2-26):

Water requirement

$$
\begin{array}{cc}
\multicolumn{2}{c}{\begin{array}{c}
\text { Water use } \\
\text { (acre-ft per year) }
\end{array}} \\
\text { Cottonwood Creek } & \text { Ferron Creek } \\
32,000 & 16,800 \\
0 & 7,000^{1} \\
354 & 129
\end{array}
$$

Agriculture

Industry

'For use at the Emery Power Plant, Utah Power shight 


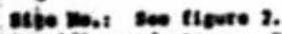

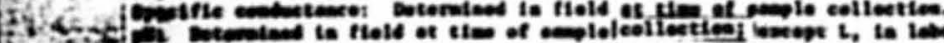

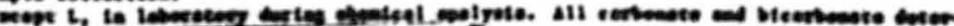

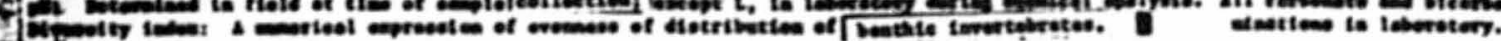

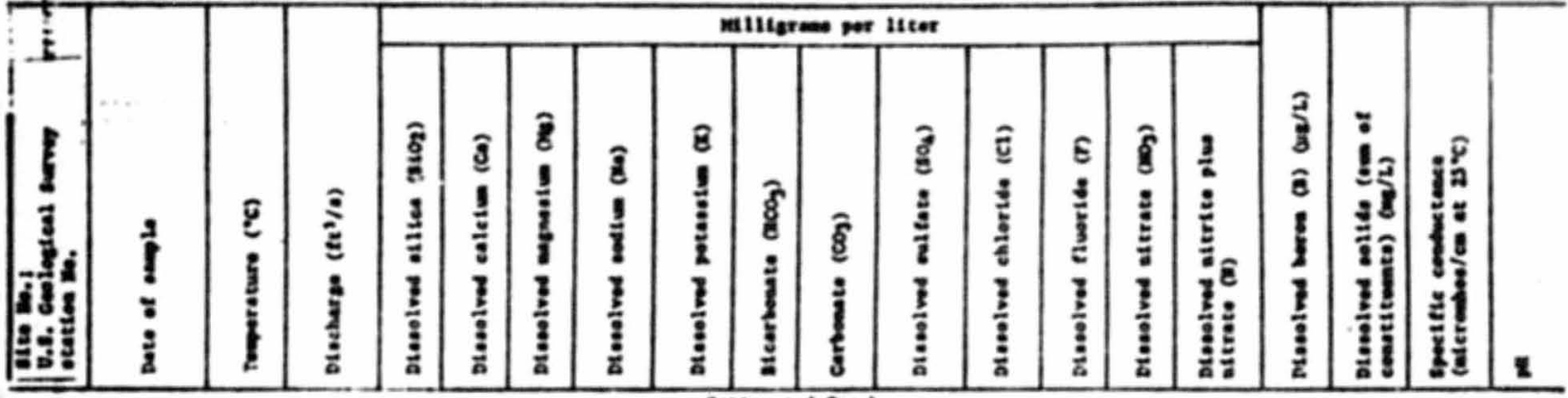

\section{3.}

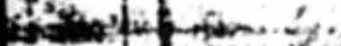

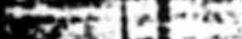

ris

78 
Table 3...-Selected vater-q̧uality date for Cottonwod and ferron Creeks.-Continued Organic, blologieal, and nutrient analyzes

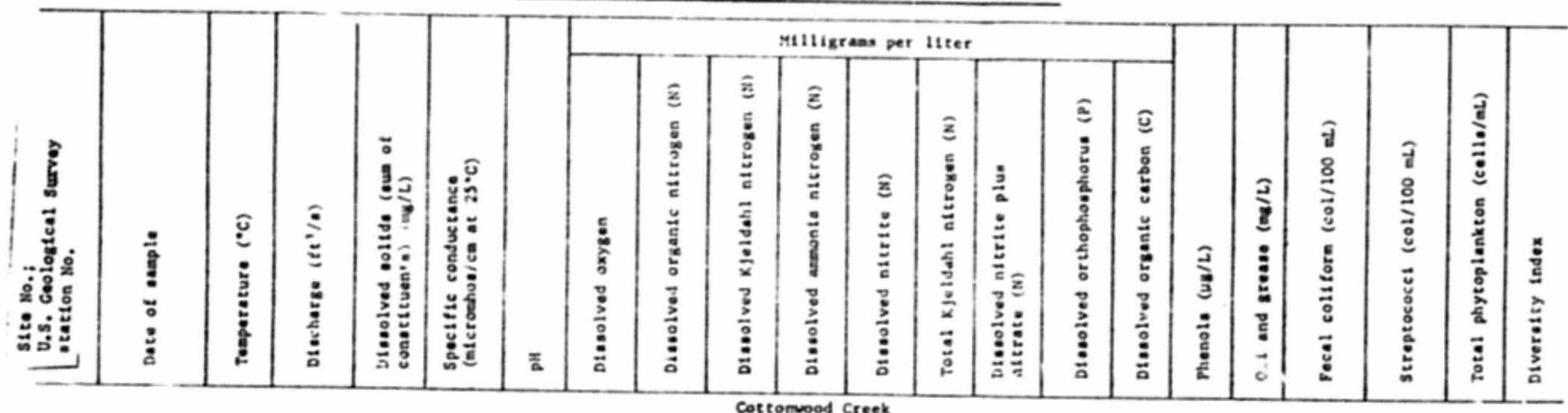

$2^{\circ}$

\begin{tabular}{|c|c|c|c|c|c|c|c|c|c|c|}
\hline \multirow{3}{*}{$\begin{array}{c}58-1 \\
09324500\end{array}$} & $\begin{array}{l}1-15-16 \\
3-17-76\end{array}$ & $\begin{array}{l}0.5 \\
3.5\end{array}$ & $\begin{array}{l}6.6 \\
9.5\end{array}$ & $:$ & $\begin{array}{l}530 \\
510\end{array}$ & 8.4 & 11.6 & 0.40 & 0.44 & $0.0 \%$ \\
\hline & $7-7-76$ & 12.0 & 200 & - & $\begin{array}{l}510 \\
390\end{array}$ & 8.4 & 10.6 & .28 & .30 & .02 \\
\hline & 9. $1-76$ & 16.5 & 164 & 210 & $\begin{array}{l}380 \\
390\end{array}$ & $\begin{array}{l}8.7 \\
8.7\end{array}$ & $\begin{array}{l}8.4 \\
8.5\end{array}$ & $\begin{array}{r}.14 \\
.61\end{array}$ & -17 & .03 \\
\hline \multirow{5}{*}{$\begin{array}{r}50-2 \\
09325000\end{array}$} & $11-4-75$ & 9.5 & 11 & 2,150 & 2,500 & 8.3 & 9.6 & .27 & .30 & 03 \\
\hline & $1-15-76$ & 0.5 & 7.4 & • & 2,400 & 7.9 & 9.2 & 1.1 & 1.7 & .55 \\
\hline & $3-17-76$ & 8.5 & 3.8 & - & 3,200 & 8.2 & 11.6 & 1.9 & 2.0 & .14 \\
\hline & $7-8-76$ & 20.0 & 21 & • & $2,00 n$ & 8.2 & 8.2 & .50 & .50 &.$\infty$ \\
\hline & $9-1-76$ & 16.5 & 6.9 & 2,160 & 2,290 & $0, t$ & 7.6 & .61 & .61 &.$\infty$ \\
\hline
\end{tabular}

\section{verron Creek}

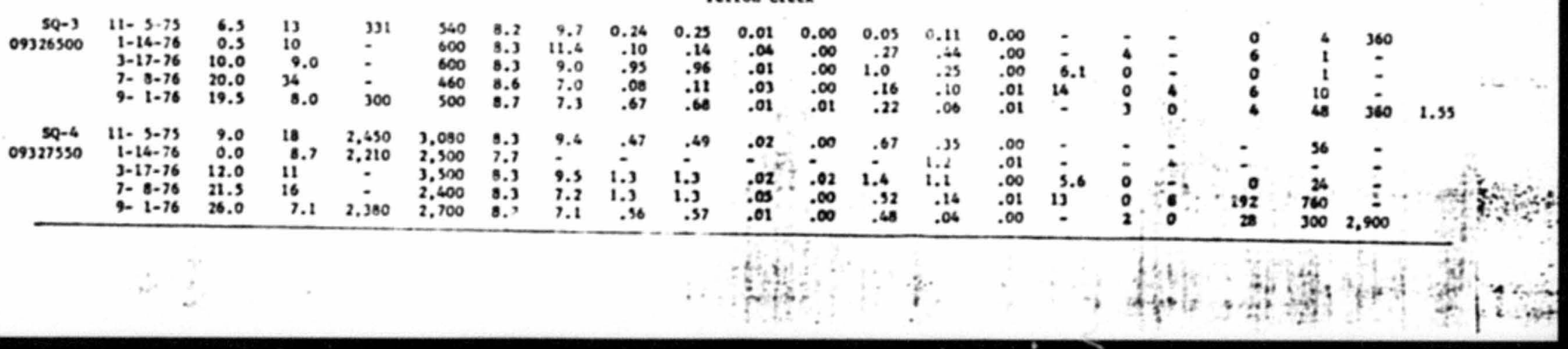


Table 3.-.-5elected vater-quallty data for cottoevood and Verron Creeka--Continued

Trace-entel analyes

\begin{tabular}{|c|c|c|c|c|c|c|c|c|c|c|c|c|c|c|c|c|c|c|c|c|c|}
\hline \multirow[b]{2}{*}{ 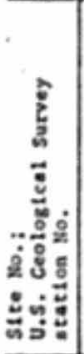 } & \multirow[b]{2}{*}{ 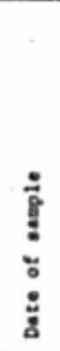 } & \multirow[b]{2}{*}{ کֶ. } & \multirow[b]{2}{*}{ 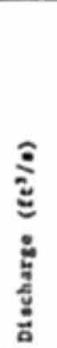 } & \multicolumn{18}{|c|}{ Merogran per liter } \\
\hline & & & & 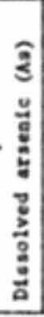 & 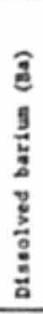 & 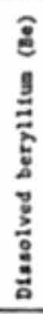 & 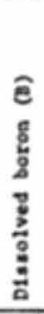 & 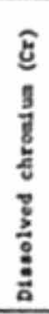 & 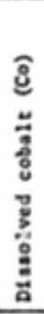 & 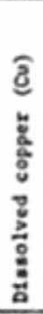 & $\begin{array}{l}\hat{\mathrm{E}} \\
\mathrm{z} \\
\mathrm{z} \\
\mathrm{z} \\
\mathrm{z} \\
\mathrm{z}\end{array}$ & 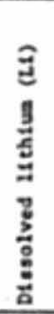 & 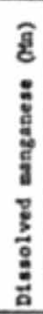 & 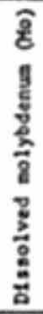 & 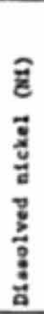 & 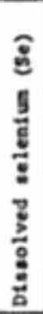 & 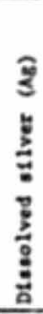 & 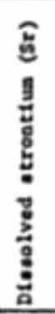 & 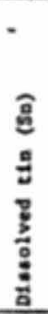 & 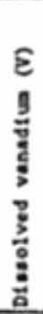 & 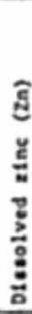 \\
\hline
\end{tabular}

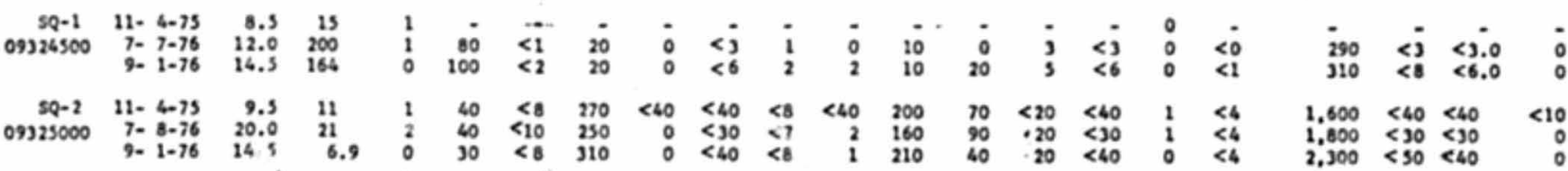

perron Creek

$\begin{array}{cccccccccccccccccccccc}50-3 & 11-5-75 & 6.5 & 13 & 1 & 20 & <3 & 20 & <7 & <7 & 10 & <7 & 20 & 10 & 5 & <7 & 0 & <1 & 770 & <7 & <7.0 & <10 \\ 03328500 & 7-8-76 & 20.0 & 34 & 1 & 100 & <2 & 10 & 0 & <7 & 2 & 2 & 20 & 20 & 3 & <7 & 0 & <1 & 730 & <10 & <6.0 & 0 \\ 9-1-76 & 19.5 & 8.0 & 0 & 100 & <3 & 40 & 0 & <8 & j & 2 & 30 & 0 & <8 & <0 & 0 & <2 & 780 & <8 & <8.0 & 0\end{array}$

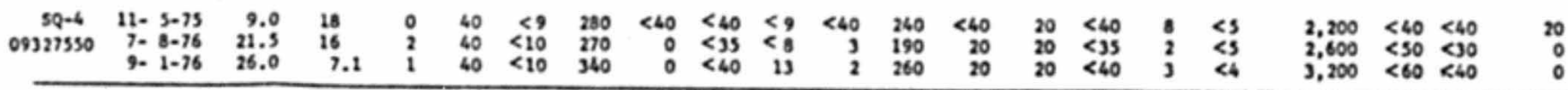



Table 4.--Measured suspended sediment in Cottonwood Creek at

$\underline{1975}$ oct. 81350 Nov. 51045 Fe $\stackrel{1976}{11} \quad 1215$ Mar. $11 \quad 1045$ May $19 \quad 1515$

June 24

July 14

Aug. 11

Sept. 15

oct. 13

Dec. 7

Mar. 2

$\begin{array}{lr}\text { Apr. } & 6 \\ \text { May } & 12\end{array}$

June 14

July 13

Aus. 10

Sct. 6

Nov. 17

Dec. 15

Jan. 11

Peb. 23

Mar. 31

$\begin{array}{ll}\text { Apr. } & 27 \\ \text { May } & 31\end{array}$

June 27

Sug. 23

$\begin{gathered}\text { Temper- } \\ \text { ature } \\ \left({ }^{\circ} \mathrm{C}\right)\end{gathered}$

10.0
3.0
.0

.0
2.0
6.0
11.5
9.0
12.5
14.0
11.5
7.5
3.0
.0

Instan- Suspended-

discharge sediment

$\underset{\left(\mathrm{ft}^{3} / \mathrm{s}\right)}{(\mathrm{mg} / \mathrm{L})}$

Suspended

sedinent

(tons/day)

14

$\begin{array}{rr}119 & 44 \\ 15 & 6 \\ 10 & 27\end{array}$

14
.24
.73

$\begin{array}{cr}16 & 46 \\ 7.4 & 0 \\ 30 & 10 \\ 134 & 33 \\ 174 & 3 \\ 210 & 22 \\ 124 & 22 \\ 65 & 178 \\ 25 & 2 \\ 7.2 & 48 \\ 10 & 7\end{array}$

$\begin{array}{rc}46 & 2.0 \\ 0 & .00 \\ 10 & .81 \\ 33 & 12 \\ 3 & 1.4 \\ 22 & 12 \\ 22 & 7.4 \\ 178 & 31 \\ 2 & .13 \\ 48 & .93 \\ 7 & .20\end{array}$

1115

1430

1445
1030

1030
1030

1030

1100

1130

1100
1130

1100

1100
1130

1130
1130
.0
14.5
13.0
16.0
11.5
11.0
9.0
9.0
2.0
.0

.0
.0
9.0
7.0
9.5
15.5
13.5
10.0
9.0
Ground Water

General conditions of occurrence

In deeply dissected terrain such as North Horn Mountain, perched aqu1fers may occur above the levels or the most deeply incised perennial streamsIn this case cottonwood and Ferron Creeks. Such aquifers probably exist at varlous depths bengath Worth Horn Mountain, as shown in figure 9. Aquifers of Price and Blackhauk Forrat! and apparently also exist in the Castlegate Sandstone 1979 by the Utah Geological and Mineral Survey extensive water-bearing zone in the Price River Fornation. During mal be an water was also occasionally found in the Castlegate Sandstone and commonly found 1. the Blackhawk Fornation above the major coal seams.

The perched aquifers support the flow of szall seeps and springs (fig. 10 and table 5) used by livestock and wildife, but these aquifers probably would not sustain large withdrawals (more than $100 \mathrm{gal} / \mathrm{min}$ ) for long periods

It appears that the regional water table extends upurd into the Blackhawk Formation in soze areas. For example, in those drill holes where water was encountered in the Blackhawk, the rocks seemed to be saturated dommard 1nto the Star Point Sandstone. The Star Point, where completely saturated, should be capable of yielding sustained quant.tis
wells; however, no y1eld estimates can be made at this time.

Recharge and movement

The principal source of ground-water recherge in the North Horn Mountain is assumed to be from precipitation. The perched aquifers beneath North Horn Mountain probably receive recharge only from local precipitation, whereas, the deeper aquifers in the main zone of saturation (fig. 9) probably receive recharge from rogional precipitation--chiefly in the higher, wetter areas west of North Horn Mountain. Water probably moves to both perched and deeper aquifers along faults, joints, or fractures, and movesent apparently is quite rapid. Evidence for this is the rapid rise in the water level in the the water level in an observation well in the Blackhawk Formation (fig.10) rose $12 \mathrm{ft}$ in August 1979 in response to large amounts of rainfali in the first week of the month. The water level had not fallen by the first week of September. Water levels in a nearby well that taps a perched aquifer in the Price River Formation (fig. 10) also responded rapidly to the same rainfall. However, by the first week of September, the water level in the observation well In the Price River Formation had declized to the level previously measured in July.

Some of the water in the main zone of saturation beneath North Horn Masing by be derived frou outside the Cottonwood and Ferron Creek drainage fault vest of Horth Horn Mrough major ?ault zones such as the Joes Valley certain this source of recharge. 


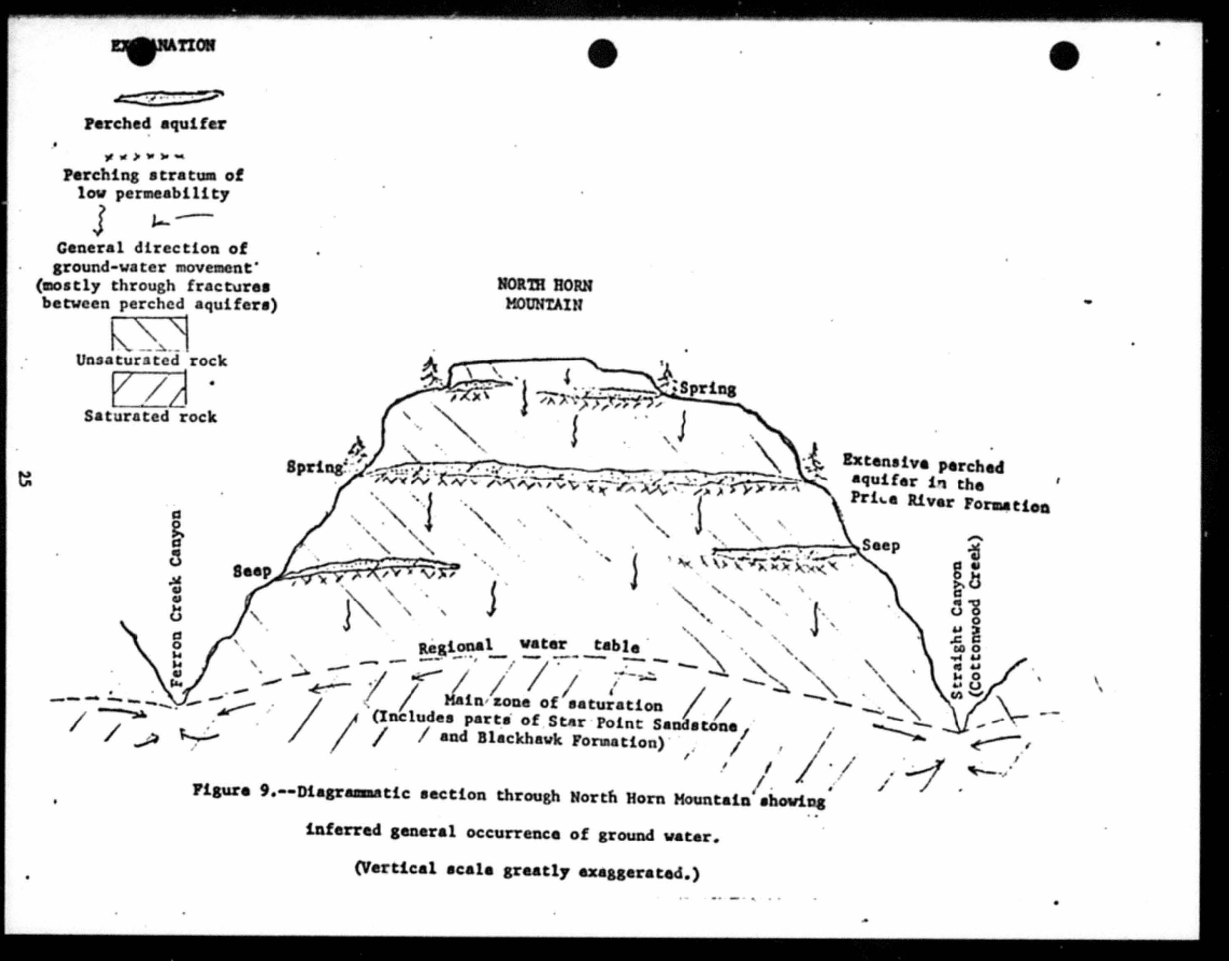




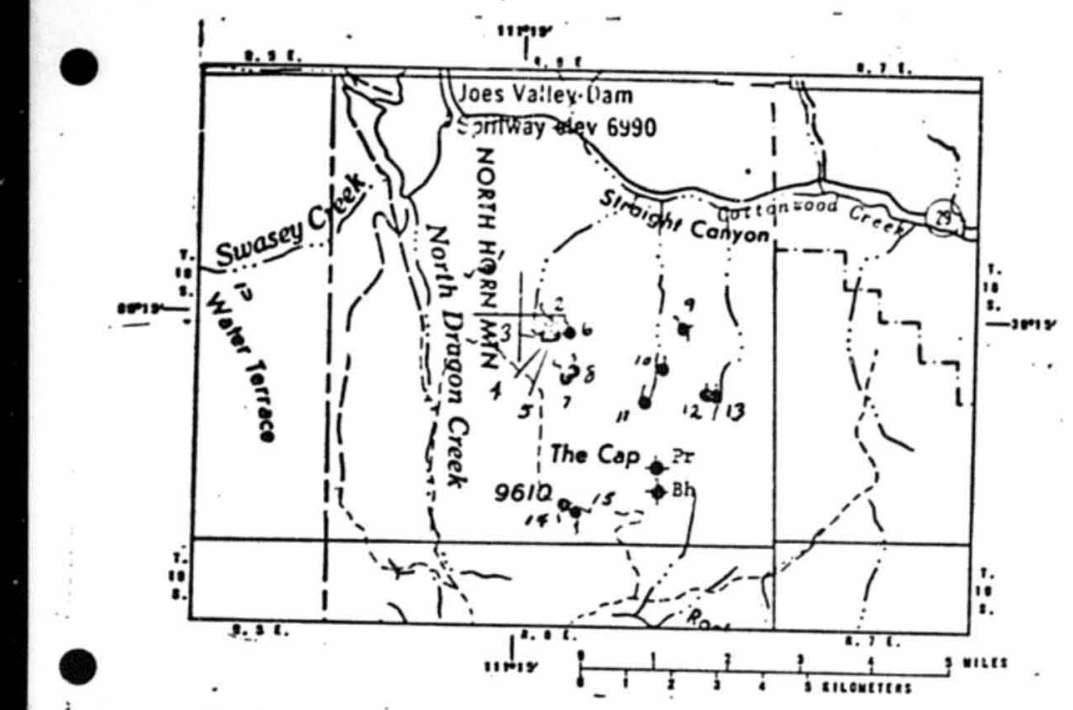

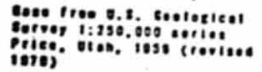

$$
\begin{aligned}
& \text { EXPLAPATION } \\
& 8 \text { or } \\
& \text { Number } 15 \text { site number } \\
& \text { in table } 5
\end{aligned}
$$

\begin{tabular}{|c|c|}
\hline $\begin{array}{l}\text { Site No. } \\
\text { (seo fig. 10) }\end{array}$ & $\begin{array}{l}\text { U C. Geological Survey } \\
\text { local No. }\end{array}$ \\
\hline $\begin{array}{l}1 \\
2 \\
3 \\
4 \\
3\end{array}$ & $\begin{array}{c}\text { (D-18-6) } 16 \mathrm{bdb}-\mathrm{S1} \\
15 \mathrm{ccc}-\mathrm{S1} \\
21 \mathrm{azs}-\mathrm{S1} \\
22 \mathrm{bbb}-\mathrm{S1} \\
15 \mathrm{ccc}-\mathrm{S} 1\end{array}$ \\
\hline $\begin{array}{r}6 \\
7 \\
8 \\
9 \\
10\end{array}$ & 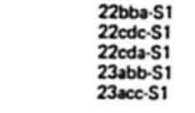 \\
\hline $\begin{array}{l}11 \\
12 \\
13 \\
14 \\
15\end{array}$ & 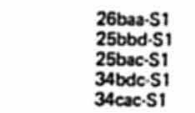 \\
\hline
\end{tabular}

\begin{tabular}{|c|c|c|c|}
\hline & $\begin{array}{l}\text { Measured } \\
\text { disch-arge } \\
\text { (gal/min) }\end{array}$ & $\begin{array}{c}\text { Timperature } \\
{\left[{ }^{\circ} \mathrm{Cl}\right.}\end{array}$ & $\begin{array}{l}\text { Soecific } \\
\text { conductane }\end{array}$ \\
\hline $\begin{array}{l}8.23 \\
8.30 \\
8.30 \\
8.24 \\
8.30\end{array}$ & $\begin{array}{r}11.1 \\
2.8 \\
.5 \\
.7 \\
1.5\end{array}$ & $\begin{array}{l}8.0 \\
8.0 \\
7.0 \\
7.0 \\
7.0\end{array}$ & $\begin{array}{r}1.500 \\
700 \\
1.150 \\
1.150 \\
700\end{array}$ \\
\hline $\begin{array}{l}8.24 \\
8.223 \\
8.23 \\
9.5 \\
8.30\end{array}$ & $\begin{array}{c}6.7 \\
39.2 \\
.3 \\
.52 \\
.3\end{array}$ & $\begin{array}{r}8.0 \\
5.0 \\
8.0 \\
12.0 \\
6.5\end{array}$ & $\begin{array}{r}1,150 \\
510 \\
610 \\
1.025 \\
790\end{array}$ \\
\hline $\begin{array}{l}6.28 \\
8.24 \\
8.24 \\
6-28 \\
6.28\end{array}$ & $\begin{array}{l}\text { (1) } \\
.5 \\
1.0 \\
-5.0\end{array}$ & $\begin{array}{l}19.0 \\
19.0 \\
17.0 \\
26.0 \\
10.0\end{array}$ & $\begin{array}{r}700 \\
1.500 \\
1.500 \\
1.600 \\
1,000\end{array}$ \\
\hline
\end{tabular}

F1gure 10.--Location of observation wells and springs investigated on Horth Horn Mountain.
Table 5.-Selected data for springs on North Horn Mountain Soecific conductance: Micromhos per centimeter at $25^{\circ} \mathrm{C}$; determined by field conductivity meter.
pH: Units determined by field $\mathrm{pH}$ meter.

'Seep, discharge too small to measure.

\section{D1scharge}

Some of the ground water in a perched aquifer discharges in seeps and springs, and some probably seeps down along joints and fractures to lower aquifers (r.g. 9). Springs generally 1ssue from the side of stream channels into which rock dips, at the contact of two formations, or above beds of contact)

The number of springs in a given formation decreases down the strat1 graphic column. Most of the springs discharge from the Flagstaff Linestone and the North Horn and Price River Formations. Springs in the Flagstaff Limestone and North Horn Formation fluctuate rapidly in discharge in response to heavy rains, but they also way dry up by late summer. The few visible prings ln the Blackhawk Forzation and Star Point Sandstone are small, ation main zone of saturthe1r helps to sustain the base 1 s probably consumed by evapotransplration. the main zone of suturation moves along faults and fratures to case water in or moves out of the drainage basins of cottonnood and Ferron Creeks.

$$
\text { Qual1ty }
$$

According to Price and Waddell (1973, sheet 2), dissolved-sollds concentrations of ground water in the North Horn Mountain area range from less 
than $500 \mathrm{mg} / \mathrm{L}$ in the headwater areas of Cottonwood and Ferron Creeks to about $1,000 \mathrm{mg} / \mathrm{L}$ along the west edge of Castle Valley. Water in the Mancos Shale beneath Castle Valley and possibly beneath the lower ends of Cottonwood and Ferron Creek canyons contaln more than $1,000 \mathrm{mg} / \mathrm{L}$ and locally may be more blghly saline.

The dissolved-solids concentrations of water from six springs in the North Horn Mounta1n area ( 1 gg. 2) range from 294 to $750 \mathrm{mg} / \mathrm{L}$ (table 6). Samples were collected from 15 other springs on dorth Horn Mountain (fig. 10), during the summer of 1979, but these sazples have not yet (December 1979) been analyzed. Field measur ts of the specific conductances of water from these springs ranged from $51 \quad 1,600$ micromhos per centimeter at $25^{\circ} \mathrm{C}$ (table 5). Th1s Indicates that dissolved-solids concentrations of these waters, which 1ssue from the Castlegate Sandstone and overlying formations, range from about 300 to $1,200 \mathrm{mg} / \mathrm{L}$.

The chemlcal quality of ground water in the Blackhawk Formation and its coal-bearing beds beneath North Horn Mountain has yet to be determined. The water may be chemically similar to that discharged from the Hilberg Mine, wh1ch is in the Blackhawk 7.5 miles northeast across Cottonwood Creek from North Horn Mountain. A water sample collected Septezber 20, 1976, from the Wilberg Mine had a dissolved-solids concentration of about $550 \mathrm{mg} / \mathrm{L}$ (Waddell and others, 1978, table 7).

\section{Use}

The principal use of ground water in the North Horn Mountain area is by wildife and livestock. This is mostly at undeveloped springs and seeps in the higher, wetter areas on and west of North Horn Mountain. Sose springs discharge to watering troughs, but there are no water-supply wells in the 1mediate vicinity of North Horn Mountain.

\section{SOME POTENTIAL IMPACTS OF COAL MINIMG ON THE WATER RESOURCES}

\section{Surface water}

Coal mining on North Horn Mountain should have an insignificant effect on the quant,ity of runoff in Cottonwood and Ferron Creeks. As noted earlier, most of the flow of those streams is generated in the higher, wetter area west of North Horn Mountain. The estimated mean annual runoff from North Horn Mountain to Cottonwood and Ferron Crteks amounts to only about 7 and 6 percent, respectively, of the average annual runoff recorded in those streams at gaging stations 09324500 and 09326500 . Even if clearing of land required to rine the coal were to increase runoff from North Horn Mountain by as much as 50 percent, which is considered high:ly unlikely, the average annual runoff at stations 09324500 and 09326500 would be increased less than 4 and 3 percent, respectively. On the otr.er hard, if runoff froz North Horn Mountain were reduced by 50 percent due to the use of runoff catchments or because of land subsidence, 1 the average annual runoff at stations 09324500 and 09326500

\footnotetext{
Land subsidence may result in fractures through which water is diverted underground.
} 


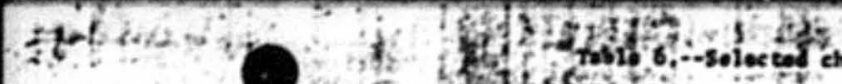
site no.t see rigure 2 ? It if

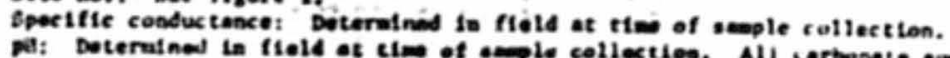

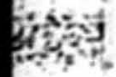

i his

\begin{tabular}{|c|c|c|c|c|c|c|c|c|c|c|c|c|c|c|c|c|c|c|c|c|c|c|}
\hline \multirow[b]{2}{*}{$\begin{array}{l}\dot{z} \\
\dot{z} \\
\dot{\vec{w}}\end{array}$} & \multirow[b]{2}{*}{$\begin{array}{l}\text { e.s. Coolozical } \\
\text { Serroy } \\
1 \propto 001 \text { ino. }\end{array}$} & \multirow[b]{2}{*}{ 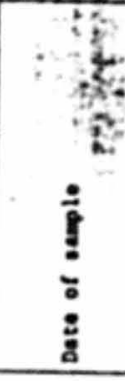 } & \multirow[b]{2}{*}{ 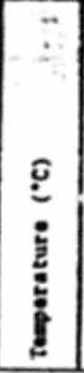 } & \multirow[b]{2}{*}{ 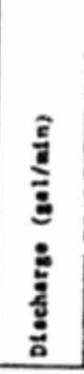 } & \multicolumn{15}{|c|}{ masitgrame per ister } & \multirow[b]{2}{*}{$\begin{array}{l}\frac{0}{0} \\
\vdots \\
\frac{5}{2} \\
\vdots \\
\vdots \\
\vdots \\
\vdots \\
\frac{0}{8}\end{array}$} & \multirow[b]{2}{*}{ 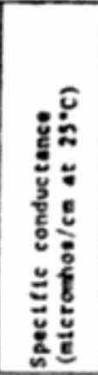 } & \multirow[b]{2}{*}{$\frac{\pi}{a}$} \\
\hline & & & & & 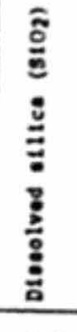 & 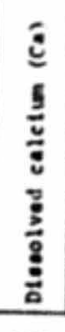 & 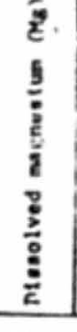 & $\begin{array}{l}5 \\
5 \\
\frac{5}{5} \\
\vdots \\
\frac{5}{0} \\
\frac{3}{0}\end{array}$ & $\begin{array}{l}\bar{\Xi} \\
\vdots \\
\vdots \\
\vdots \\
\vdots \\
\vdots \\
\vdots \\
\vdots \\
\vdots\end{array}$ & $\begin{array}{l}\bar{E} \\
\underline{E} \\
\vdots \\
\vdots \\
\vdots \\
\vdots \\
\vdots \\
\vdots\end{array}$ & 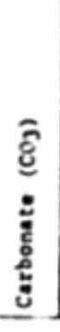 & $\begin{array}{l}\bar{g} \\
\vdots \\
\vdots \\
\vdots \\
\vdots \\
\vdots \\
\vdots \\
\vdots \\
\vdots\end{array}$ & 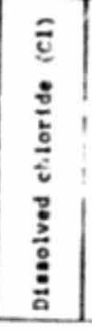 & 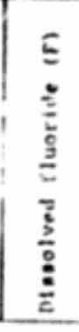 & 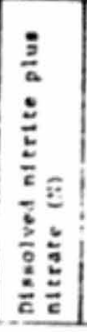 & 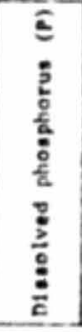 & $\begin{array}{l}\bar{s} \\
\vdots \\
\vdots \\
\vdots \\
\vdots \\
\tilde{y} \\
\vdots \\
z\end{array}$ & 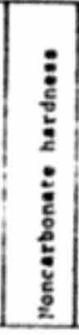 & 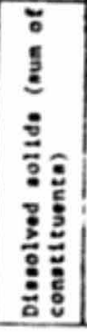 & & & \\
\hline $\begin{array}{l}\infty-1 \\
\infty-2 \\
\infty-3 \\
\infty-6 \\
\infty-5 \\
\infty-6\end{array}$ & $\begin{array}{r}(D-17-7) 27 \text { aca-s1 } \\
28 b a d-51 \\
(D-18-5) 35 d 4 a-51 \\
(D-15-6) 31 d c a-51 \\
(D-19-6) 6 a 0 d-51 \\
204 b a-51\end{array}$ & $\begin{array}{r}9-29-76 \\
10-22-76 \\
9-28-76 \\
9-2 b-76 \\
9-76-76 \\
9-26-76\end{array}$ & $\begin{array}{r}10.0 \\
3.5 \\
16.0 \\
9.0 \\
16.0 \\
8.5\end{array}$ & $\begin{array}{l}1.2 \\
2.7 \\
1.0 \\
1.2 \\
.20 \\
2.7\end{array}$ & $\begin{array}{l}9.5 \\
5.9 \\
4.3 \\
6.8 \\
7.8 \\
12\end{array}$ & $\begin{array}{r}120 \\
63 \\
35 \\
34 \\
51 \\
19\end{array}$ & $\begin{array}{l}81 \\
32 \\
40 \\
60 \\
59 \\
5.1\end{array}$ & $\begin{array}{r}26 \\
14 \\
20 \\
110 \\
83 \\
280\end{array}$ & $\begin{array}{r}4.5 \\
.8 \\
2.5 \\
1.0 \\
2.5 \\
.6\end{array}$ & $\begin{array}{l}376 \\
361 \\
327 \\
326 \\
447 \\
746\end{array}$ & $\begin{array}{l}0 \\
0 \\
0 \\
0 \\
0 \\
0\end{array}$ & $\begin{array}{r}300 \\
33 \\
11 \\
100 \\
47 \\
38\end{array}$ & $\begin{array}{l}18 \\
3.7 \\
17 \\
61 \\
88 \\
21\end{array}$ & $\begin{array}{r}0.1 \\
.2 \\
.2 \\
.3 \\
.4 \\
1.2\end{array}$ & $\begin{array}{l}1.3 \\
.26 \\
.61 \\
2.0 \\
.13 \\
.07\end{array}$ & $\begin{array}{l}0.00 \\
.00 \\
.00 \\
.01 \\
.00 \\
.02\end{array}$ & $\begin{array}{l}630 \\
290 \\
250 \\
380 \\
370 \\
69\end{array}$ & $\begin{array}{r}330 \\
0 \\
0 \\
0 \\
6 \\
0\end{array}$ & $\begin{array}{l}750 \\
332 \\
296 \\
662 \\
560 \\
743\end{array}$ & $\begin{array}{r}0.5 \\
.4 \\
.5 \\
2.5 \\
1.9 \\
15\end{array}$ & $\begin{array}{r}1,000 \\
575 \\
535 \\
820 \\
910 \\
1,120\end{array}$ & $\begin{array}{l}7.3 \\
8.5 \\
8.0 \\
7.5 \\
8.4 \\
8.3\end{array}$ \\
\hline
\end{tabular}

\begin{tabular}{|c|c|c|c|c|c|c|c|c|c|c|c|c|}
\hline \multirow[b]{2}{*}{$\begin{array}{l}\dot{\rho} \\
\stackrel{2}{*}\end{array}$} & \multirow[b]{2}{*}{$\begin{array}{c}\text { t.s. Geological } \\
\text { survey. } \\
\text { Ixal to. }\end{array}$} & \multirow[b]{2}{*}{$\begin{array}{l}\dot{\overrightarrow{0}} \\
\mathbf{g} \\
\dot{\mathbf{g}} \\
\mathbf{z}\end{array}$} & \multicolumn{10}{|c|}{ Micrograms per liter } \\
\hline & & & 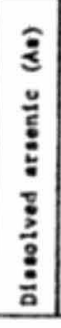 & 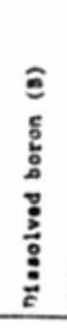 & 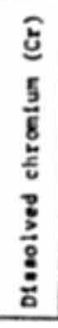 & 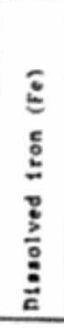 & $\begin{array}{l}\bar{E} \\
\bar{E} \\
\vdots \\
\vdots \\
\bar{z} \\
\bar{z} \\
\vdots \\
\vdots \\
\vdots\end{array}$ & 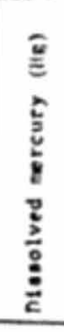 & 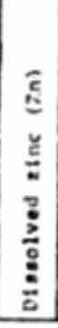 & 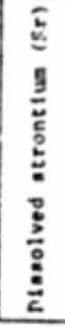 & 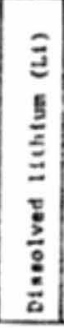 & 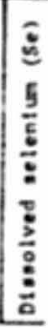 \\
\hline $\begin{array}{l}c \alpha-1 \\
\infty-2 \\
\infty-3 \\
\infty-4 \\
\infty-5 \\
\infty-6\end{array}$ & 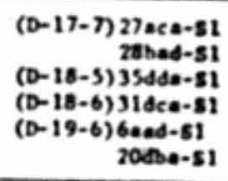 & $\begin{array}{r}9-29-76 \\
10-22-76 \\
9-28-76 \\
9-28-76 \\
9-28-76 \\
9-28-76\end{array}$ & $\begin{array}{l}0 \\
1 \\
0 \\
1 \\
3 \\
i\end{array}$ & $\begin{array}{r}100 \\
20 \\
60 \\
90 \\
100 \\
200\end{array}$ & $\begin{array}{r}0 \\
10 \\
0 \\
0 \\
0 \\
0\end{array}$ & $\begin{array}{r}20 \\
30 \\
20 \\
10 \\
30 \\
140\end{array}$ & $\begin{array}{l}1 \\
3 \\
0 \\
0 \\
0\end{array}$ & $\begin{array}{l}0.1 \\
.3 \\
.3 \\
.0 \\
.1 \\
.0\end{array}$ & $\begin{array}{r}10 \\
10 \\
0 \\
10 \\
0 \\
10\end{array}$ & $\begin{array}{l}780 \\
320 \\
550 \\
470 \\
460 \\
100\end{array}$ & $\begin{array}{l}30 \\
10 \\
30 \\
20 \\
40 \\
20\end{array}$ & $\begin{array}{l}1 \\
1 \\
2 \\
3 \\
1 \\
1\end{array}$ \\
\hline
\end{tabular}

i....... 
would be reduced by less than 4 and 3 percent, respectively. The decrease probably could be even less, assuming that some water diverted underground
through subsidence fractures would eventually reach the streams--either through seeps or by aine drainage.

Considerable water would be required for dust suppression and other activities associated with =ining, processing, and transporting of coal. The most likely source of such water is Cottonwood Creek, which is already fully appropriated (mostly for irrigation). Consequently, existing water rights economy accordingly.

Coal mining on North Horn Mountain probably would have only a minor effect on the quality of surface water in the area. However, sediment yields extent of 1 ht increase significantly during periods of construction. The extent of areas disturbed, :ype of gitigation, and weather conditions during construction periods. As noted earller, 90 percent or wore of the sediment load in the San Rafael River is produced during 10 percent or less of the tize dur to the effect of cloucburst hoods. Ir construction were to take place sediment loads of the affected streas. This would add to the cost of treating the water used for public supply. Construction during other tiees of the year, provided proper aitigating zeasures were taken, probably would not significantly increase fluvial-sediment loads above natural levels.

Data are 1nsurficient to evaluate potential 1=pacts of coal mining on North Horn Mountain on the chenical and biological quality of surface water in the area. Such mining will lnerease the potental for the increased population contaninants, such as fuel oll, Into waterways. The Increased population streamflow in Cottonwood and Ferron Creeks, thus creating health hazards and Increasing the cost of water treatment for public supply.

The coal seams beneath North Horn Mountain dip to the west and probably extend into the main zone of saturation. Consequentiy, if that coal is mined, mine drainage may be required and the mine water way be discharged to a surface drainage. The effect on surface-water quality probably would be Insignificant because of the relatively scall amcunt of ground water that wave about the he as the runorf during lou-runoff (bageflow) periods and would be greatly diluted during high-runorf periods. Furthermore, mine water cannot legally be discharged to a stream if it does not meet State of Utah Class C water-quality requirements (Utah Division of Health, written comun., 1971).

Ground water

Potential 1mpacts on ground water that might result from mining of coal on North Horn Mountain are inferred largely from information gained in on North tor Moutan particularly East Mountain (about 7 miles to the northeast across Cottonwood Creek from Horth Horn Mountain). As noted earlier, it appears that much, if not all, the ground water above the coal in North Horn Mountain is in perched be extensive. Subsiden perched aquifers, as in the Price River Formation, way create rock fractures through which a perched aquifer aight be drained, thu depleting the flow of seeps or springs fed by that aqu' "er. Should thi occur, wildlife or livestock aight have to find an alternate water source.

Mining of coal on North Horn Mountain may require scme mine dewatering which alght result in interbasin transfer of water. That 1s, some ground water naturally tributary to Ferron Creek could be diverted to Cottonwood Creek via the mine-drainage facility (assuming aine portals to be in cotton canyon). The volune of mine-diverted water probably would be 1nvolved. However, the interbasin transfer of that water by the mine could lead to legal probleas involving water rights.

It 1s unlikely that mining of the coal on the North Horn Mountain will adversely affect the chesical quality of the ground water. Available data Indicate that the water in and above the coal-bearing beds is fresh, generally of hydralic connection vorkings, or subsidence fractures rould not significantly incress the dissolved-sollds concentration of the less af neralized water in one aquifer or decrease the dissolved-solids concentration of the more aineralized water in the other. It is considered extresely unlikely that exploration drilling (which 1s usually to the top of the Star Point Sandstone) or coal-mining operations (all above the Star Point) would create hydrologic cornections between the saline water-bearing Mancos Shale and the fresh water-bearing Star Point. Mining of coal on the North Horn Mountain, however, would introduce the potential of contamination of water in the Star Point by accidental spills taminants could seep to the Star "uint.

conclusions

1. Coal mining on North Horn Mountain should have an insignificant effect on the quantity of runoff in Cottonwood and Ferron Creeks. The maximum
predicted decrease in the annual flow in these streams would be less than 4 percent.

2. The quality of the surface water probably would not be degraded to any major extent by the mining. However, if construction were to $t-k e$ place dur1ng the summer cloudburst season,

3. The coal mining on North Horn Mountain will increase the potential for unpredictable spills of contaninants, such is fuel oil, into waterways.

4. Subsidence, which usually follows underground coal mining, could create rock fractures throush whe a perched anufrer nt aht be dralned, thu depleting the flow of seeps or springs fed by that aquifer. 
5. It is considered unlikely that mining of the coal on North Horn Mountain w1ll adversely affect the chemical quality of the ground water. However, thr mining would i troduce the potential of contamination of water in the Star Point Sandstone by accidental spills of fuel oil or other contaminants on mine floors from wrence those contaminants could seep to the Star Point. 


\section{REFERENCES CITED}

Bagley, J. M., Jeppson, R. W., and Mill1gan, C. M., 1964, Water yields in Otah: Otah Agricultural Experiment Station Special Report 18, 65 p.

Doelling, H. d., 1972, Central Utah coal fields: Sevits-Sanpete, Wasatch Plateau, Book Cliffs, and Enery: Utah Geological and Mineralogical Survey Monograph 3, p. 59-242.

Fenneman, W. M., 1931, Physiography of Western United States: New York, MeGraw-Hill Book Co., 534 p.

Iorns, W. V., Heabree, C. H., and Oakland, G. L., 1965, Water resources of the Opper Colorado River Basin--Technical Report: U.S. Geological Survey Professional Paper 441, 370 p.

Johnson, J. L., 1978, Stratigraphy of the coal-bearing Blackhawk Formation on North Horn Mountain, Wasatch Plateau, Utah: Utah Geological and Mineral Survey, Utah Geology, v. 5, no. 1, p. 57-77.

Price, Don, and Wadde11, K. M., 1973, Selected hydrologic data in the upper Colorado River Basin: U.S. Geological Survey Hydrologic Investigations
Atlas HA-477, scale, $1: 250,000$.

Spleker, E. M., 1931, The Wasatch Plateau coat field, Utah: U.S. Geological Survey Bulletin $819,210 \mathrm{p}$.

Stokes, W. L., 1964, Geologic map of Utah: University of Utah, scale 1:250,000.

0.S. Department of the Interior, 1979, Final environmental statement, Emery project: U.S. Departzent of the Interior open-file release, 684 p.

D.S. Water Resources Counc1l, 1977, Guidelines for determining floodflow Prequency: U.S. Water Resources Council Hydrology Comittee Bulletin 17A., 26 p.

ס.S. Weather Bureau, (no date a), Normal annual and May-September precip1tation $(1931-60)$ for the State of Utah: Map of Utah, scale 1:500,000.

0.S. Weather Bureau, (no date b), Normal annual October-April precipitation (1931-60) for the State of Utah: Map of Utah, scale 1:500,000.

Madde11, K. M., V1ckers, H. L., Upton, R. T., and Contratto, P. R., 1978, Selected hydrologic data, 1931-77, Wasatch Plateau-Book Cliff's coalFields area, Utah: U.S. Geological Survey Open-File Report 78-121 (đuplicated as Utah Basic-Data Release 31), 33 p.

Wadde11, R. M., Cortratto, P. K., Sumsion, C. T., and Butler J. R., 1979, Bydrologic reconnaissance of the Wasatch Plateau-Book Cliffs coal-fields area, Utah: U.S. Geological Survey Open-File Report 79-988, $57 \mathrm{p}$. 